\title{
Analyses of Total Quality Management Implementation through ISO 9001: 2015 Standard Approach
}

\author{
Hamdan Amaruddin \\ Pelita Bangsa University, Indonesia \\ \{Hamdanamar@pelitabangsa.ac.id\}
}

\begin{abstract}
Objective: This research is intended to analyze the application of TQM, through an ISO 9001: 2015 quality management system approach, in one of the companies located in the largest industrial area in Southeast Asia, Jakarta. Methodology: The research design used is an ISO 9001: 2015 schematic diagram, the operational variable used is Total Quality Management along with its principles, data collection is performed by interview and observation methods, while the data analysis uses radar charts. Findings: The results showed that from the full score of 10 achievements for the principle of customer focus 7.5, leadership 8 , people involvement 7.5 , process approach 6 , strategic and systematic approach of management 7.5 , continuous improvement 6 , factual approach 5 , and mutual benefit of supplier relationship 6.5. Form 8 principles of TQM, only the leadership principle has reached a score of 8 , while the other principles are still below the target. Implications: To improve the application of TQM, all ISO requirements that have been outlined in the form of procedures must be carried out with discipline. Originality: This research can provide details of the problems faced by the research object so that it can be used as a reference for corrective action.
\end{abstract}

Keywords: TQM, ISO 9001:2015, PDCA

\section{Introduction}

The term Total Quality Management (TQM) is now commonly known in the industrial world because most of the company's management accepts this management system as a comprehensive system and it is considered to have capability of improving company performance. However the claims were based on different methods. Some company claim, that they have implement TQM, based on Crosby's 14 steps of quality improvement, some are based on 14 points of Deming's suggestion, some are based on Juran's 10 steps towards quality improvement, some are based their claim because they have applied Ishikawa diagrams, others claim because they have already implementing Six Sigma, Malcolm Baldrige Framework, Balance Score Card, European Foundation For Quality Management (EFQM), and an ISO 9001 quality management system. All of these concepts, although they have their own characteristics, share some of the same commitments: (a) The importance of management commitment; (b) Strategic approach to the quality system; (c) The importance of quality measurement; (d) The importance of process improvement; (e) Education and training; (f) Eliminating the causes of quality problems.

In this research, the authors will use the ISO 9001: 2015 Quality Management System 
approach as a means to analyze the application of total quality management at a company engaged in the electronics field which is located in the industrial area in East Jakarta. The variable used is TQM along with its 8 principles. These 8 principles are tallied with the clauses of ISO 9001:2015 standard. Research method used is case-study. The mains step of this research are: (a) Plotting a matrix between 8 principles of TQM with the clauses of ISO 9001:2015 standard, (b) Establishing checklist based on ISO 9001:2015 requirements; (c) Conduct interviews with employees and observe the direct implementation of TQM in the field; (d) Confirmation the finding to person in charge of quality; (e) Creating summary report of interview and observation result. This study will provide a clear picture of how TQM is implemented, because it traces in detail about the application of the ISO 9001: 2015 standard requirements. This study did not simplify the assessment of the quality management system by a simple sentence which was then consulted with respondents with different levels of understanding about quality management system. The simplification meant by the researcher here is to make a statement that represents all dimensions.

For example the dimensions of product quality like performance, reliability, durability, features, safety, and ease of service are simply represent by a statement, namely products quality. Then this statement of products quality is asked to various respondents who do not necessarily have the same perception about the quality dimension [1]. Another thing that encourages the authors to conduct research using qualitative methods are heterogeneous of jobs, and authorities which is lead to different knowledge, skills and experience among the respondent [2]. With the characteristics of respondents like this it would be very difficult to conduct quantitative research because one detailed statement about one aspect of quality management could not be answered by all respondents. Only certain respondents who have job relationship with these aspects can answer questions or statements. For example, statements about procurement of goods may only be responded to by the employee in purchasing department while employee in other section will not be able to provide an accurate response because they do not have an access to the data and information about it. [3][10]

Research on the application of TQM has been carried out by various parties. In general, their research is intended to discover obstacles to the successful implementation of TQM and the effect of the application of TQM on organizational performance. In this study, TQM as a management system is considered to be well recognized by many parties and the focus of research is to discover how effective the application of TQM systems in a company by using the ISO 9001: 2015 quality management system approach [4]. The previous studies more emphasis on success and obstacles in the application of TQM by studying the application of TQM using a very varied method. TQM itself does not have a requirement that is a common benchmark for companies. So the claims of one company already have implemented TQM will most likely be very different from the same claim from other companies [5]. This study takes ISO 9001: 2015 requirements as a means to assess the success of a manufacturing company in implementing TQM. The existence of strict requirements will help companies in assessing how far TQM has been applied.

\section{Literature Review}

\subsection{TQM}

TQM according to many experts in quality have different pillars, some say it has 4 principles, some says it has 6 principles. In this study, researcher will use TQM with 8 pillar (Russle and 
Taylor 2008) As well known, there are eight main pillars in TQM namely; (a) customer focus, (b) leadership, (c) people involvement, (d) process approach, (e) strategic and systematic approach of management, (f) continuous improvement, (g) factual approach, and (h) mutual benefit of supplier relationship [6][10].

\subsection{ISO 9001: 2015 Standard}

ISO 9001:2015 Quality management systems - Requirements is a document of approximately 30 pages available from the national standards organization in each country. Contents of ISO 9001:2015 consist of main idea as follows: (a) Context of the organization; (b) Leadership; (c) Planning; (d) Support; (e) Operation; (f) Performance evaluation; (g) Continual Improvement Essentially, the layout of the standard is follows the Plan, Do, Check, Act cycle in a process-based approach but is now further encouraging this to have risk-based thinking.

\subsection{Conceptual Framework}

The researcher will use a bagan of ISO 9001: 2015 standard as a reseach desain. Sumber standard ISO 9001: 2015.

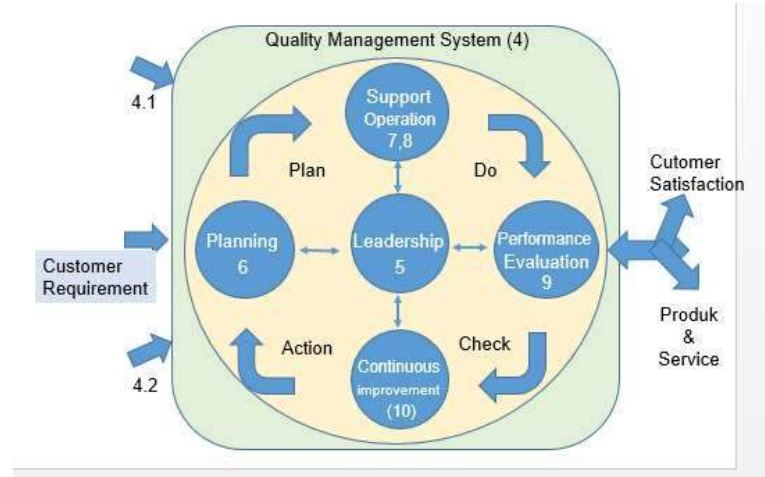

Fig.1. Research Design

From the chart above which is used as a research design, it can be seen how ISO 9001: 2015 seeks to accommodate the principles of TQM. Considering that ISO 9001: 2015 can represent the application of TQM, the researcher decided to study the implementation of TQM in an electronics company in Indonesia using the requirements contained in these standards.

\section{Research Methods of Study}

To collect data I made a checklist based on ISO 9001: 2015 requirements. Then the checklist is used as a guide for conducting interviews and observations to collect data needed in research. Checklist created using a measurement scale of 1 to 5 for each question. The weighting rules for the measurement scale can be seen in the table definition of operational variables. The interviews and observations on companies that are in the largest industrial area in Asia were conducted during June 2020. The population used as the object of this study were all employees 
in intended electronic companies, the number of samples was highly dependent on the development of issues in the field. The sampling method used is purposive sampling for each section.

Table 1. Operational variable

\section{Variables Indicators Scale}

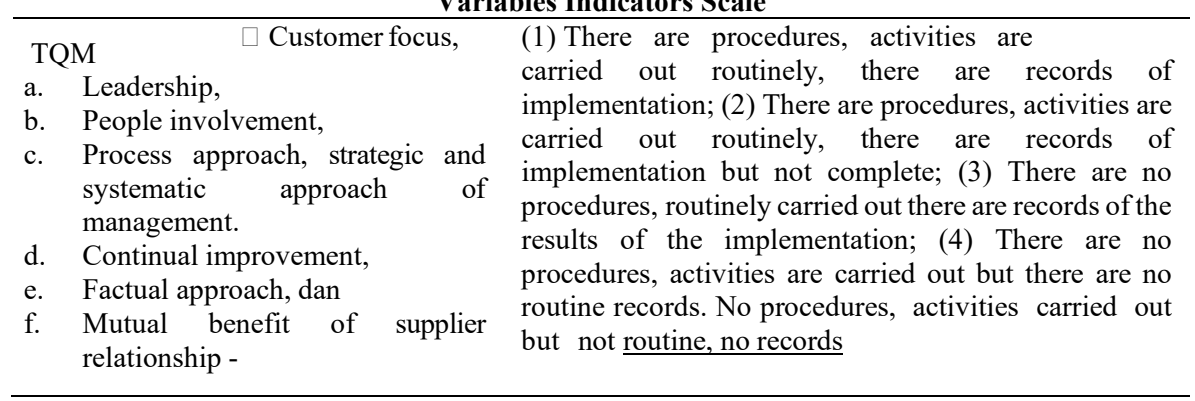

The analytical method used is as follows: After the data is collected using a checklist, the total achievement value is calculated using the formula:

Achievement Persentage $=\frac{\text { totaS Score } 100 \%}{\text { fuSS ccaSe }}$

After that the results are outlined in the form of a radar chart [7]. After that, a discussion was held for the TQM principle that had not yet reached optimum results. Overall results are said to be good if the acquisition of a minimum score of $80 \%$. When the score is still carried out at $80 \%$, an analysis is carried out by discussing the root of the problem that causes the acquisition of a small score.

\section{Result and Discussion}

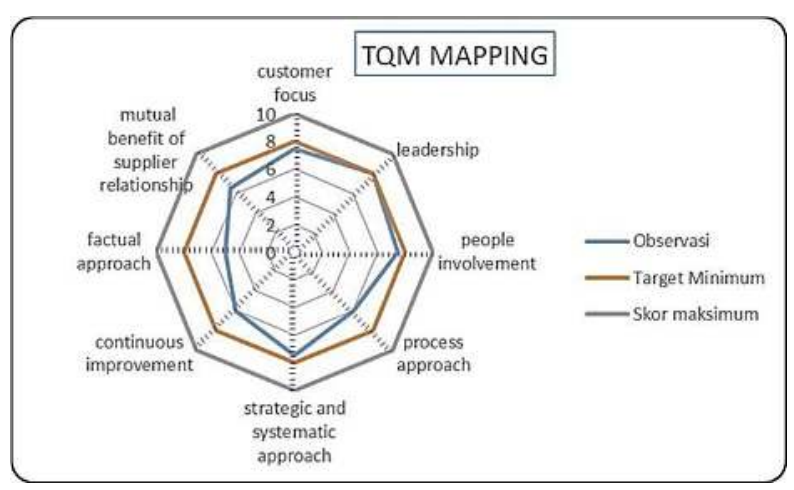


Fig.2. Result of TQM Mapping

The results of the study can be seen in the picture above. Each axis represent the TQM principle in sequence. From the graph we can see that achievement for the principles of TQM are: customer focus 7.5, leadership 8, people involvement 7.5, process approach 6, strategic and systematic approach of management 7.5, continuous improvement 6 , factual approach 5 , and mutual benefit of supplier relationship 6.5. From the 8 principle of TQM, only the leadership principle has reached a score of 8 , while the other principles are still below the target.

From the results of mapping the $8 \mathrm{TQM}$ principles above, the overall implementation of TQM using the ISO 9001: 2015 approach is still below the expected target. The achievement of first principles about customer focus only reached score 7.5 due to some cases found during the observing of customer requirements, the researcher still found several instances where customer orders are not reconfirmed to customers. This case resulting in production scheduling errors for inductive components that being exported. Shipments for models requested by customers do not meet the quota while other models accumulate in the warehouse of finished goods. The principle of leadership is considered to have reached the target but it is still possible for further improvement to reach the maximum scale. The critical problem that occurs in principle of people involvement is the discovery of procedure about QCC (Quality Control Circle) but this procedure is not carried out routinely as specified in the procedure itself. According to employees who were interviewed and confirmed by the QC manager that there was an increase in production target so there was no free time to conduct QCC performances. In addition, the corrective action to problems arise were based on top-down instruction.

This case certainly wasting opportunities for more effective improvement, because employees actually knew the root of the problem that occurs but were not given the opportunity to put forward their ideas for improvement. The fifth principle about processapproach cannot reach the target because there were findings in production line where some operator who conduct their job did not based on working instructions [11]. When these findings were confirmed, it was known that their working instructions were put in the chief's desk drawer. The reason given was that the employee were experienced in doing his work. The researcher proved the skill of the employee by asking what points they needs to pay attention to during the process of doing real work, the answers were from 9 points of concern only 4 can be remembered well. The fifth principle about the strategic and systematic approach of management. Problem founds in this principle were the quality plan from all levels of management had been arranged well but the follow-up actions to achieve the target were still not going well. So there were some plans that have not been realized [12].

The sixth principle about continuous improvement. From the whole principles, the application of this principle was still far from expectations. The continuous improvement procedure already exists but the contents of the procedure did not provide adequate tools to make continuous improvement efforts [13][14]. The implementation of PDCA was not included in the procedure, so it seems that the improvement was only done in two steps, namely Do and Check without any Plan and Action. The seventh principle about factual approach. Implementation of this principle was still far from expectations. Recording of all activities in all sections were not performing in accordance with the provisions that already set out in the existing procedures. The mostcommon case found that the daily check-sheets were not filled in every day. Those were found in the production line, in the maintenance section, and in the warehouse section. When researchers asked for a daily check-sheet records for the past 3 months, it was discovered that 2 months had been filled well but the last month were still empty. This indicates that the problem could not be identified right away. For example, the some 
column in daily temperature check-sheet on a dipping solder machine and some check-sheets for torque screw drivers were empty. Since knowing this problem the researchers tried to ask further whether they do temperature checks every day, it turns out that they did the activity but they did not record in the check sheet. The eight principle is about mutual benefit of supplier relationship. The ISO 9001: 2015 requirements stipulate that components can only be purchased from approved suppliers. It turns out that some of these components are purchased from suppliers that are not included in the list of approved suppliers. The reason is the price were cheaper. Whereas in the supplier approval procedure in that section, it is stated that the purchase of components is not merely considering price issues but there are other aspects including quality, delivery time and financial capability of the supplier.

\section{Limitation}

From the results of the discussion above it can be concluded that the application of TQM with the ISO 9001: 2015 approach in one of the companies in the Jababeka industry area still needs to be improved because not all of the requirement have been verified in the detail. The employee in the company is familiar with ISO 9001:2015 since they will face internal and external audit of quality and also familiar with term TQM but did not know what to prepare in achieving TQM.

\section{References}

[1] Nasim, K. (2018), "Role of internal and external organizational factors in TQM implementation: A systematic literature review and theoretical framework", International Journal of Quality \& Reliability Management, Vol. 35 No. 5, pp. 10141033. https://doi.org/10.1108/IJQRM-10-2016-0180

[2] S. and Ohtaki, S. (2019), "Critical success factors for TQM implementation among manufacturing SMEs: Evidence from Japan", Benchmarking: An International Journal, Vol. 27 No. 2, pp. 473-498. https://doi.org/10.1108/BIJ-01-2019-0037

[3] Saleh, R.A., Sweis, R.J. and Mahmoud Saleh, F.I. (2018), "Investigating the impact of hard total quality management practices on operational performance in manufacturing organizations: Evidence from Jordan", Benchmarking: An International Journal, Vol. 25 No. 7, pp. 2040-2064. https://doi.org/10.1108/BIJ-05-2016-0074

[4] Sinha, N., Garg, A.K., Dhingra, S. and Dhall, N. (2016), "Mapping the linkage between Organizational Culture and TQM: The case of Indian auto component industry", Benchmarking: An International Journal, Vol. 23 No. 1, pp. 208-235. https://doi.org/10.1108/BIJ-12-2014-0112

[5] Bajaj, S., Garg, R. and Sethi, M. (2018), "Total quality management: a critical literature review using Pareto analysis", International Journal of Productivity and Performance Management, Vol. 67 No. 1, pp. 128-154. https://doi.org/10.1108/IJPPM-07-2016-0146

[6] Anholon, R., Simon Rampasso, I., Cooper Ordonez, R.E., Silva, D.d., Quelhas, O.L.G. and Leal Filho, W. (2018), "Observed difficulties during implementation of quality management systems in Brazilian manufacturing companies", Journal of Manufacturing Technology Management, Vol. 29 No. 1, pp. 149-167. https://doi.org/10.1108/JMTM-12-2016-0167

[7] Sahoo, S. (2019), "Assessment of TPM and TQM practices on business performance: a multi- sector analysis", Journal of Quality in Maintenance Engineering, Vol. 25 No. 3, pp. 412- 434. https://doi.org/10.1108/JQME-06-2018-0048

[8] Sahoo, S. (2019), "Assessment of TPM and TQM practices on business performance: a multi- sector 
analysis", Journal of Quality in Maintenance Engineering, Vol. 25 No. 3, pp. 412- 434. https://doi.org/10.1108/JQME-06-2018-0048

[9] Mehralian, G., Nazari, J.A., Rasekh, H.R. and Hosseini, S. (2016), "TOPSIS approach to prioritize critical success factors of TQM: Evidence from the pharmaceutical industry ", The TQM Journal, Vol. 28 No. 2, pp. 235-249. https://doi.org/10.1108/TQM-03-2014-0028

[10] Talapatra, S. and Uddin, M.K. (2019), "Prioritizing the barriers of TQM implementation from the perspective of garment sector in developing countries", Benchmarking: An International J ournal, Vol. 26 No. 7, pp. 2205-2224. https://doi.org/10.1108/BIJ-01-2019-0023

[11] Sahoo, S. (2018), "An empirical exploration of TQM, TPM and their integration from Indian manufacturing industry", Journal of Manufacturing Technology Management, Vol. 29 No. 7,pp. 1188-1210. https://doi.org/10.1108/JMTM-03-2018-0075

[12] Kumar, V. and Sharma, R.R.K. (2017), "An empirical investigation of critical success factors influencing the successful TQM implementation for firms with different strategic orientation", International Journal of Quality \& Reliability Management, Vol. 34 No. 9, pp. 1530- 1550. https://doi.org/10.1108/IJQRM-09-2016-0157

[13] Bajaj, S., Garg, R., Sethi, M. and Dey, S. (2019), "Classification and positioning of TQM practices for implementation in steel industries: An AHP approach", International Journal of Q uality \& Reliability Management, Vol. 36 No. 9, pp. 1556-1573. https://doi.org/10.1108/IJQRM07-2018-0196

[14] G.S. Oliveira, J.E. Corrêa, P.P. Balestrassi, R.A. Martins \& J.B. Turrioni (2019) Investigation of TQM implementation: empirical study in Brazilian ISO 9001-registered SMEs, Total Quality Management \& Business Excellence, 30:5-6, 641-659, DOI: 10.1080/14783363.2017.1328273 